\title{
PEMANFAATAN INFORMASI OLAHRAGA DI MEDIA MASSA CETAK OLEH GURU PENDIDIKAN JASMANI DAN KESEHATAN DALAM PEMBELAJARAN PENDIDIKAN JASMANI DAN KESEHATAN DI SMA 5, SMA 6, SMA 11 SEMARANG
}

\author{
Ahmad Muhaimin \\ (sm_muha@yahoo.co.id) \\ Dosen Pendidikan Olahraga Universitas Semarang
}

\begin{abstract}
Utilization of information in mass media print by master of physical education and health in physical education and health in SMA 5, SMA 6, SMA 11 Semarang. The presence of print media is now a community needs. That's because, the print media presents a variety of information including information of actual politics, culture, economy, crime, entertainment, and sports. Basically, sports information in the print media have educational value and can add insight to a reading of new knowledge. The study produced these findings: (1) third physical education and health teacher at school who becomes the object research have made use of sports information in the print media to support the success of teaching and learning process, (2) the type of information they use to support the success of learning teaching is a form of news, articles about health, (3) form of utilization is appropriate to set clipping and through direct delivery of the material in the field while providing practice in the field. This method is considered more effective because all students can immediately practice, (4) sports information in the print media meets the needs of teachers and physical health education in supporting the learning process.
\end{abstract}

Keywords: sports information, the print media, the health and physical education teachers.

\section{PENDAHULUAN}

\section{Latar Belakang}

Kehadiran media massa cetak dalam kehidupan umat manusia sudah berlangsung sejak berabad-abad lalu, bahkan sulit dipastikan secara tepat, kapan sebenarnya media massa cetak mulai hadir. Manusia modern tidak lagi dapat hidup tanpa mendapatkan suguhan media massa yang memenuhi kebutuhan masyarakat akan informasi. Namun kenyataannya, masih banyak masyarakat belum sepenuhnya memahami dan menyadari manfaat informasi dari media massa.

Menurut mantan Ketua PGRI Jateng, Karseno, informasi di media massa mengandung unsur pendidikan, sehingga menambah wawasan bagi yang membacanya. Dia mengibaratkan, guru yang tidak pernah membaca informasi di media massa, ibarat katak dalam tempurung. Sebab, dalam mencerdaskan anak didik, selain berpedoman pada acuan yang ada, guru juga harus menambah wawasan yang dapat diperoleh antara lain dari media massa cetak seperti surat kabar dan majalah.

Menurut Mantan Ketua PWI Jateng, Soejipto, informasi olahraga di media massa penting untuk diketahui masyarakat, karena selain menjadi tahu mengenai kemajuan ilmu dan teknologi di dunia olahraga, juga mengetahui kemajuan atau kemunduran prestasi atlet dari daerah atau negara sendiri dan atlet manca negara. Bagi pelajar, informasi olahraga di media massa sangat 
dibutuhkan, karena setiap informasi olahraga yang berbentuk berita, artikel atau iklan bisa menjadi pengetahuan tambahan.

Menurut Singgih D. Gunarsa (1996: 155), media berperan besar agar atlet merasa didukung untuk menampilkan seluruh kemampuannya dan tidak sebaliknya yakni menuntut prestasi atlet dan kemenangan. Dalam pemuatan berita olahraga, ada tujuan tertentu yang ingin dicapai oleh setiap media massa. Selain ingin ikut andil dalam memasyarakatkan olahraga juga memberikan pendidikan kepada masyarakat khususnya mengenai pentingnya olahraga serta memberikan pengetahuan tentang perkembangan dunia olahraga.

Berdasarkan latar belakang tersebut di atas menunjukkan bahwa pemanfaatan informasi olahraga di media massa cetak dalam pendidikan jasmani dan kesehatan di sekolah menegah atas penting diteliti.

\section{Metodologi Penelitian}

Penelitian ini merupakan penelitian deskriptif kualitatif. Menurut Syafi'i (1995: 15), deskriptif kualitatif adalah pembahasan permasalahan dalam penelitian yang bertujuan untuk menggambarkan atau menguraikan tentang keadaan atau fenomena, dalam hal ini pemanfaatan informasi olahraga di media massa cetak dalam pendidikan jasmani dan kesehatan di Sekolah Menengah Atas (SMA) 5, 6 dan 11 di Kota Semarang.

Untuk subjek penelitiannya adalah guru pendidikan jasmani dan kesehatan di SMA yang dipilih sebagai tempat penelitian. Menurut Moleong (1998: 112), kata-kata dan tindakan orang yang diamati atau diwawancarai merupakan sumber data utama. Semua hasil wawancara, observasi, pengamatan atau pengambilan data lainnya dicatat melalui catatan tertulis atau melalui perekam atau audio tape, pengambilan foto atau file.

Setelah peneliti memperoleh surat izin penelitian, peneliti segera mempersiapkan kerangka kerja yang akan digunakan untuk menggali data yakni berupa pedoman atau panduan lapangan. Setelah panduan lapangan dibuat, peneliti segera mulai melakukan pendekatan kepada subjek penelitian. Kegiatan selanjutnya adalah mengambil data dengan cara wawancara, observasi (pengamatan), dan dokumentasi.

Analisis data dan interpretasi data dilakukan sejak data itu diperoleh. Dalam kegiatan ini yang dilakukan peneliti adalah membaca dan mempelajari secara teliti seluruh data yang sudah terkumpul, yaitu hasil dari kegiatan wawancara, observasi atau pengamatan, dan dokumentasi.

Pada tahapan ini, peneliti mencatat semua hasil peneliti tanpa membuang sedikit pun walaupun ada data yang kurang relevan dengan tujuan penelitian. Setelah data itu terkumpul kegiatan selanjutnya adalah mereduksi data yaitu memilih dan memilah data dengan cara menghilangkan atau mengurangi data yang tidak sesuai dengan tujuan pendidikan. Setelah mereduksi data ialah menyajikan data. Data dalam penelitian ini disajikan dengan cara mendeskripsikan (menguraikan) semua masalah berdasarkan hasil wawancara, pengamatan, dan dokumentasi yang disajikan dalam bentuk foto kegiatan dalam pemanfaatan informasi olahraga di media massa cetak.

Sebagai kegiatan akhir dari analisis data adalah kegiatan interpretasi data. Di dalam kegiatan ini peneliti mengaitkan pemanfaatan informasi olahraga di media massa cetak dengan kenyataan di lapangan berdasarkan penelitian. Jika dalam penyajian data masih ada yang kurang, peneliti segera kembali mengadakan pengumpulan data untuk melengkapi kekurangan data yang dibutuhkan. 
PEMBAHASAN

1. Pemanfaatan Informasi Olahraga di Media Massa Cetak dalam Pendidikan Jasmani dan Kesehatan di SMA 5, SMA 6, dan SMA 11 Semarang

Dalam pelaksanaan pendidikan jasmani dan kesehatan di SMA 5 Semarang, ada dua bentuk kegiatan yaitu kegiatan kurikuler dan ekstrakulikuler. Kegiatan kurikuler meliputi kegiatan pokok dan kegiatan pilihan.

Untuk kegiatan pokok terdiri atas: senam, permainan dan atletik. Sedangkan, kegiatan pilihan terdiri atas: pencak silat, sepak takraw, softbal, renang, bulutangkis, tenis meja dan yudo.

Berdasarkan wawancara dan pengamatan langsung terhadap Guru Pendidikan Jasmani dan Kesehatan SMA 5 Semarang, Cornelis, sebelumnya memberikan materi pelajaran kepada siswa, dia sering membaca buku sebagai pedoman mengajar.

Agar bisa mengikuti perubahan dalam permainan salah satu cabang olahraga dan perubahan peraturan mainnya, Cornelis membeli buku terbaru untuk bekal dia mengajar. Bahkan menurut Cornelis, untuk menambah wawasan tentang informasi olahraga yang terjadi setiap hari, dia setiap hari membaca Surat Kabar Suara Merdeka dan Wawasan.

"Saya setiap pagi sebelum berangkat mengajar selalu menyempatkan waktu sebentar untuk membaca koran Suara Merdeka. Yang saya baca pertama ketika saya membaca Suara Merdea adalah halaman olahraga, kemudian baru halaman pertama. Yang sering saya ikuti berita olahraga bulutangkis dan sepak bola. Misalnya menjelang kejuaraan All England, kejuaraan dunia, Piala Sudirman dan Piala Thomas, saya selalu mengikuti beritanya," ujar Cornelis.

Alasan kebiasaan Cornelis membaca Suara Merdeka antara lain, beritanya aktual, bahasanya mudah paling pagi, sehingga dia bisa dimengerti dan datangnya membaca berita-berita olahraga dan berita aktual lain, meskipun tidak tuntas. Selain Suara Merdeka dan Wawasan, dia juga sering membaca Tabloid Bola. Hanya, dia tidak berlangganan Tabloid Bola.

Berkaitan dengan hal tersebut di atas, Cornelis menuturkan: "Informasi dari surat kabar sangat bermanfaat. Sebab, saya kadang-kadang memberi pengetahuan umum tentang olahraga kepada siswa, misalnya menjelaskan adanya peraturan baru cabang olahraga yang saya peroleh dari membaca koran. Demikian pula, jika ada siswa bertanya tentang berita olahraga yang aktual seperti hasil kompetisi Liga Indonesia atau kejuaraan bulutangkis All England dan Tenis Wimbledon, saya malu jika tidak bisa menjawab pertanyaan seputar olahraga yang sedang aktual diketahui masyarakat," tutur Cornelis

Dari pengamatan langsung Peneliti, SMA 5 Semarang berlangganan Suara Merdeka. Koran tersebut berada di ruang guru, sehingga semua guru bisa membaca. Bagi guru yang tidak mengajar pada jam pertama, biasanya mereka membaca koran di ruang tamu guru. Setelah selesai, surat kabar tersebut diletakkan di meja ruang tamu guru. Meskipun sekolah telah berlangganan Suara Merdeka, beberapa guru ada yang membawa surat kabar sendiri. Jenis surat kabar yang dibawa guru bermacam-macam antara lain, Kompas, Suara Merdeka, Nova, Jawa Pos, dan Nyata, sesuai kesukaan mereka.

Bagi guru pendidikan jasmani dan kesehatan, informasi olahraga dipandang penting untuk menambah wawasan khususnya mengenai berita aktual olahraga, baik hasil pertandingan sepakbola, bola basket, bola voli dan cabang cabang lain. Bukan hanya itu, tulisan atau artikel juga menambah pengetahuan baru. Sebab, dalam setiap tulisan biasanya ditunjukan persoalan dan 
pemecahannya. Informasi-informasi seperti itu, bisa dibaca dalam surat kabar yang terbit setiap hari di kota Semarang seperti yang dibaca Harun, Guru Pendidikan Jasmani dan Kesehatan SMA 6 Semarang.

Dia tertarik membaca surat kabar karena memiliki manfaat ganda. Pertama, bermanfaat bagi dirinya, karena dengan membaca berita-berita olahraga di surat kabar, dia memperoleh tambahan pengetahuan. Kedua, bermanfaat bagi anak didiknya, karena setelah menyampaikan pengetahuan yang didapat dari membaca surat kabar, anak didiknya menjadi tahu perkembangan olahraga di tingkat dunia, nasional dan daerah.

Menurut Donald P. Ely yang dikutip Sudarwan Danim (1994: 13), salah satu manfaat media teknologi pendidikan adalah pengajaran dapat dilakukan secara mantap dikarenakan meningkatnya kemampuan manusia sejalan dengan pemanfaatan media komunikasi, informasi dan data dapat disajikan lebih konkret dan rasional.

Menurut Harun, dia paling suka jika ada berita tentang atlet Jawa Tengah (Jateng) yang berhasil mengukir prestasi bagus dalam event nasional dan internasional. Sebab, berita tersebut selain mengharumkan nama daerah juga bisa memotivasi atlet Jateng lain untuk berprestasi yang lebih baik. Berita-berita seperti itu, menurut Harun sangat baik untuk diketahui siswa. Sebab, selain menambah pengetahuan, juga merangsang minat siswa untuk menukai dan menekuni salah satu cabang olahraga.

"Setelah membaca Suara Merdeka, saya merasa ada manfaat yang bisa saya serap. Terutama berita tentang prestasi atlet Jepang. Saya senang membaca berita seperti itu, karena selain saya sendiri ikut bangga, juga bisa ditiru oleh para siswa," kata Harun.

Untuk memilih jenis surat kabar harus selektif, karena yang dibutuhkan adalah informasi yang akurat, sekarang banyak beredar surat kabar yang menyajikan informasi kurang akurat, kurang mendidik, dan pornografi. Media seperti itu, kurang tepat jika dibaca oleh guru dan siswa.

Seorang guru yang ingin berhasil dalam proses belajar mengajar, tentu harus memilih surat kabar yang informasi bermanfaat bagi dirinya. Berkaitan ini, Harun menuturkan: "Saya suka membaca Suara Merdeka, karena berita-beritanya aktual dan banyak mengangkat prestasi atlet Jateng. Selain berita, Suara Merdeka juga memuat tulisan-tulisan tentang olahraga, profil atlet dan tulisan ringan tentang kehidupan atlet Jateng seperti Chris John, Kurniawan Dwi Yulianto, Bambang Pamungkas dan Tanti Pratiwi," ungkap Harun.

Media yang dibaca Harun itu cukup bermanfaat, karena berita-berita yang dimuat di Suara Merdeka memang banyak yang bisa dimanfaatkan untuk bekal mengajar. Namun sebenarnya masih ada surat kabar yang isi beritanya lebih berbobot dalam memberikan pengetahuan kepada pembaca seperti Kompas, Media Indonesia, Suara Pembaruan, Jawa Pos, dan Tabloid Bola. Kompas misalnya, sering memuat tulisan analisis tentang pembinaan cabang-cabang olahraga antara lain, tenis lapangan, bulutangkis, sepakbola dan catur. Selain berita olahraga, Kompas juga menyajikan artikel tentang kesehatan, ekonomi, budaya dan politik yang ditulis secara mendalam.

Hal itu tentu sangat berguna isinya bagi yang membaca. Pemanfaatan beritaberita olahraga di Suara Merdeka, Kompas, Jawa Pos, dan Tabloid Bola tampaknya sudah diterapkan oleh guru pendidikan jasmani dan kesehatan SMA 6, seperti yang dituturkan Harun: "Tulisan olahraga yang dimuat di Suara Merdeka dan Kompas, kadang memberikan inspirasi saya ketika sedang mengajar, sehingga saya bisa memberikan tambahan 
pengetahuan kepada siswa."

Sementara itu, menurut Muhammad Ali, media pengajaran merupakan bagian dalam sistem pengajaran. Media pengajaran diartikan sebagai segala sesuatu yang dapat digunakan untuk menyalurkan pesan, merangsang pikiran, perasaan, perhatian dan kemauan siswa sehingga dapat mendorong proses belajar mengajar (1987: 88-89).

Ini menunjukkan bahwa informasi dalam media massa memiliki manfaat yang cukup besar dalam merangsang pikiran, perasaan, perhatian, dan kemauan siswa dalam proses belajar mengajar.

\section{Bentuk dan Cara Pemanfaatan} Informasi Olahraga di Media Massa Cetak di SMA 5, SMA 6, SMA 11 Semarang

Meskipun ada kesamaan antara materi pelajaran olahraga dan materi informasi olahraga yang ada di media massa cetak, tidak setiap pertemuan, guru memberikan tambahan materi pelajaran dari media massa cetak. Namun pada prinsipnya, guru pendidikan jasmani dan kesehatan setuju bila informasi olahraga di media massa cetak memiliki manfaat dalam mendukung keberhasilan proses belajarmengajar.

Tidak setiap pertemuan belajar mengajar, Guru Pendidikan Jasmani dan Kesehatan SMA 5 Semarang, memberikan tambahan pengetahuan umum yang diperoleh dari membaca di media massa cetak. Namun, pemberian informasi dari media massa cetak, disesuaikan dengan materi pelajaran yang akan diberikan. Misalnya, pada saat memberikan materi pelajaran bulutangkis, maka dia bisa bercerita tentang prestasi pebulutangkis Indonesia di tingkat dunia. Demikian pula, bila materi pelajaran sepakbola, cerita tentang kepiawaian legendaris sepakbola dari Argentina (Diego Mardona) dan Pele dari Brasil bisa menjadi cerita yang menarik bagi para siswa.

Menurut Cornelis, materi pelajaran dan informasi olahraga di media massa ada kesamaan. Dia tidak bisa memberikan di setiap mengajarnya, karena dia terikat dengan kurikulum yang ada. Di kurikulum, guru diharuskan memberikan materi pelajaran sesuai dengan tahapan materi yang diajarkan. Sementara informasi olahraga di media massa hanya bersifat informasi umum, sehingga informasi yang agak teknis tidak ada.

"Saya kadang-kadang saja memberikan informasi olahraga dari media massa cetak. Sebab, dalam proses belajar mengajar saya dituntut memberikan materi pelajaran sesuai yang ada dalam kurikulum. Sehingga, saya lebih banyak memberikan materi teknik sesuai kurikulum. Biasanya, kalau saya memberikan informasi olahraga umum hanya sebagai tambahan saja dengan cara mengaitkan sesuai dengan cabang olahraga yang saya ajarakan. Misalnya, jika pelajaran sepak bola, saya ingatkan bagaimana Maradona menendang bola dengan baik. Jika pelajaran bola basket, saya bisa bercerta tentang Michael Jordan melakukan tembakan tiga angka, sedangkan jika bulutangkis, saya menyisipkan cerita tentang pemain legendaris Rudy Hartono dan Liem Swie King. Harapan saya, anak-anak selain mendapat tambahan pengetahuan juga bisa termotivasi untuk menyukai cabang olahraga tertentu," kata Cornelis.

Mengenai waktu penyampaian, Cornelis menuturkan, biasanya dilakukan pada saat dia menjelaskan teori teknik bermain sepakbola, bulutangkis, atau bola voli. Pada saat menerangkan teori itulah dia menyisipi cerita tentang perkembangan olahraga yang paling aktual, sesuai materi siswa, dia membuka kesempatan para siswa untuk bertanya. Cara lain, adalah dengan menerangkan melalui praktek langsung. Misalnya, pada saat memberikan materi pelajaran bola voli, para siswa disuruh bermain dengan sistem skor baru yakni really point. Sambil 
bermain, para siswa diminta untuk ikut menghitung dengan sistem really point, sehingga dengan begitu, para siswa akan cepat tahu tentang sistem really point seperti yang dimaksud dalam pemberitaan dimedia massa cetak tentang hasil hasil pertandingan kejuaraan bola voli.

"Saya sering memberikan tugas kliping. Biasanya, tugas itu saya berikan saat ada berita tentang kejuaraan bulutangkis, atletik, voli, dan sepakbola. Kliping yang telah dikumpulkan, kemudian saya pilih yang menurut saya terbaik untuk ditempel di papan majalah dinding. Bentuk tugas lain, saya sering menyarankan kepada para siswa agar mengikuti berita-berita olahraga di media massa, karena setelah itu saya akan bertanya kepada mereka," kata Cornelis.

Dalam pengamatan langsung di lapangan, peneliti tidak melihat ada kliping berita olahraga, artikel olahraga atau foto-foto atlet yang menempel di papan majalah dinding yang dipasang di lingkungan sekolah. Sebaliknya, papan majalah dinding terkesan tidak dimanfaatkan secara optimal, terbukti papan tersebut banyak yang kosong.

Mengenai tugas kliping seperti yang dikatakan Cornelis setelah dikonfirmasi ke siswa, Cornelis memang pernah memberi tugas membuat kliping olahraga. Bentuk tugas kliping-nya adalah berita-berita olahraga sesuai materi pelajaran yang diajarkan.

Menurut Syahrina, Siswa Kelas II.2, kliping yang dikumpulkan diperoleh dari Surat Kabar Suara Merdeka, Wawasan dan Tabloid Bola. "Pak Cornelis pernah memberikan tugas mengumpulkan kliping olahraga hasil kejuaraan bulutangkis All England. Pak Cornelis juga pernah menugasi membuat kliping tulisan tentang kesehatan," kata Syahrina.

Berdasarkan informasi dari siswa itu menunjukkan bahwa Cornelis telah memanfaatkan media massa cetak untuk keberhasilan belajar mengajar.
Pada prinsipnya, ada kesamaan cara dalam pemanfaatan informasi olahraga di media massa yang dilakukan oleh Guru Pendidikan Jasmani dan Kesehatan SMA 5 Semarang dan Guru Pendidikan Jasmani SMA 6 Semarang. Kesamaan tersebut terletak pada penugasan kepada siswa dalam penyampaian informasi olahraga dari surat kabar yang diberikan bersamaan dengan kegiatan praktek di lapangan. Cara itu dinilai paling efektif dan mengenai sasaran, sebab dengan cara tersebut, siswa bisa langsung mempraktekkan penjelasan yang diberikan guru.

Sedangkan yang membedakan dalam pemanfaatan informasi olahraga di SMA 6 Semarang adalah bentuk informasinya. Bentuk informasi yang kerapkali dimanfaatkan oleh Guru Pendidikan Jasmani dan Kesehatan SMA 6 Semarang adalah jenis artikel atau tulisan tentang kesehatan. Siswa kerapkali mendapat tugas membuat kliping tentang tulisan yang menyangkut kesehatan. Berkaitan dengan hal ini Harun menuturkan: "Saya biasanya memberikan tugas membuat kliping. Tugas kliping itu sebagai tugas kelompok. Informasi yang dikliping adalah artikel kesehatan misalnya tulisan tentang bahaya narkoba."

Menurut Harun, tugas kliping itu, biasanya diberikan pada saat pelajaran teori di dalam kelas. Pemberian tugas kliping diharapkan bisa menambah pengetahuan para siswa akan pentingnya menjaga kesehatan tubuh. Sedangkan untuk tugas kliping yang mengangkut informasi terbaru, dilakukan jika ada pemecahan prestasi yang dibuat oleh atlet Jateng pada kejuaraan tingkat nasional maupun internasional seperti PON, SEA Games, dan Asian Games. Hal itu dimaksudkan untuk memotivasi siswa khususnya siswa yang memiliki hobi terhadap satu cabang olahraga. "Kalau ada peraturan baru dari cabang olahraga yang dimuat di media massa, saya pasti menyampaikan ke siswa," tuturnya. 
Menurut Harun, dia tidak pernah memasukkan informasi dari media massa ke dalam soal ujian, sebab dia sudah menyampaikan informasi dari media massa itu pada saat mengajar praktek. Kalaupun ada tugas membuat makalah tentang olahraga dimaksudkan sebagai bentuk tugas pengayaan. "Bentuk tugas seperti membuat makalah atau tugas membaca dan mencerna isi informasi di media massa sebagai tugas pengayaan," tutur Harun.

Cara yang ditempuh Harun itu, memang terkait dengan materi pelajaran yang diajarkan. Bahkan ketika dikonfirmasikan ke siswa, mereka membenarkan pernah diberi tugas mengumpulkan kliping. Bentuk tugasnya juga sama yaitu mencari artikel tentang kesehatan. Namun karena tugas yang dibebankan merupakan tugas kelompok, sehingga hanya beberapa siswa tertentu yang membuat tugas kelompok. Karena itu, harapan agar siswa bisa menjalani hidup sehat kurang mengena sasaran.

"Dalam memberikan tugas membuat kliping, pak Harun kerapkali menyuruh untuk mencari artikel tentang kesehatan, tapi juga pernah membuat kliping tentang hasil kejuaraan bola voli dan bola basket," kata Mahmudah, Siswi Kelas II.

Dalam pengamatan di lapangan, peneliti tidak menemukan kliping yang dipasang di papan majalah dinding. Justru yang terpampang adalah tulisan puisipuisi karya siswa. Sedangkan, tugas kliping kelompok seperti yang pernah diberikan guru pendidikan jasmani dan kesehatan sudah tidak ada lagi.

Gaya guru dalam mengajar antara satu dengan lain tidak sama. Dalam cara menyampaikan materi pelajaran pun bisa berbeda. Ada yang hanya berpatok pada kurikulum, ada pula yang suka menyisipkan materi tambahan yang diperoleh dari membaca buku atau media massa.

$\mathrm{Bu}$ Retno, Guru Pendidikan Jasmani dan Kesehatan SMA 11 Semarang, termasuk guru yang tidak pernah memberikan tugas kepada siswanya untuk membuat kliping olahraga. Alasannya, selain jauh dari sasaran materi yang diajarkan, juga menambah beban pekerjaan. Seandainya dia ingin memberikan pengetahuan dari media massa, biasanya dia sampaikan pada saat menjelaskan teori materi yang akan diajarkan di lapangan.

"Sambil menjelaskan, saya minta dipraktekkan langsung. Untuk mengetahui respons siswa, saya selalu bertanya apa yang telah saya berikan. Bagi siswa sudah membaca berita surat kabar, pasti bisa menjawab," ujar Retno.

Apa yang ditempuh oleh Retno itu merupakan evaluasi langsung yang dilakukan secara lisan dan tindakan atau perbuatan. Evaluasi seperti itu merupakan salah satu faktor penting dalam proses belajar mengajar. Dalam pelaksanaannya, evaluasi itu mempunyai manfaat sangat besar. Sementara itu, berdasarkan pemaparannya Muhammad Ali, ada empat jenis evaluasi yaitu evaluasi formatif, evaluasi sumatif, evaluasi diagnosik, dan evaluasi penempatan (1987: 113-114).

Dalam evaluasi sumatif, Retno mengatakan, tidak pernah memberikan tes teori, karena penilaian dalam mata pelajaran olahraga sekarang diambil dari hasil tes praktek dan sikap. Apa yang dilakukan Retno sudah sesuai dengan peraturan baru, dimana berdasarkan kurikulum pendidikan jasmani dan kesehatan tahun 1994 yang telah disempurnakan dan diberlakukan mulai tahun ajaran 1998-2000, mata pelajaran olahraga tidak ada penilaian yang bersifat teori (tes tertulis). Penilaian untuk mata pelajaran olahraga hanya didasarkan pada tes praktik dan sikap.

Meskipun Retno tidak memberikan tes teori, tapi dia tidak berusaha mencari jalan untuk memberikan tambahan wawasan kepada anak didiknya. Misalnya, 
memberikan tugas membuat makalah atau diskusi kelompok khususnya tentang informasi yang sedang aktual di media massa. Dengan cara itu, secara tidak langsung akan mendidik siswa dalam memahami dam menambah pengetahuan tentang olahraga.

Dalam pengamatan langsung, memang tidak ada kliping olahraga yang dipampang di papan majalah dinding di sekolah. Bahkan ketika dikonfirmasikan ke siswa, mereka mengaku tidak pernah mendapatkan tugas membuat kliping. Sewaktu masih ada tes teori, siswa juga mengaku materi materi tes cukup sulit, karena materi yang diteskan masalahmasalah teknis cabang olahraga tertentu. Menurut siswa, dari sejumlah materi tes, tidak ada yang materi tesnya bersifat pengetahuan umum. "Sekarang tes olahraga hanya tes praktek saja. Katanya sih selain tes praktek, ada juga tes sikap, tapi selama ini tidak ada tes sikap khusus," kata kuswanto, Siswa Kelas II.

Hal itu menunjukkan bahwa pemberian pemahaman yang dilakukan oleh Retno selaku guru pendidikan jasmani dan kesehatan kepada siswa telah mengena. Hal tersebut bisa merangsang minat siswa untuk menekuni salah satu cabang olahraga.

\section{PENUTUP}

Ketiga guru pada sekolah yang menjadi obyek penelitian memiliki kesadaran tinggi untuk membaca informasi di media massa cetak khususnya informasi olahraga. Hal itu terbukti, mereka setiap hari membaca informasi di media massa cetak khususnya Surat Kabar Suara Merdeka. Mereka juga merasakan manfaatnya setelah membaca informasi olahraga di media massa cetak, sebab jenis informasinya bukan hanya berupa berita, tapi juga artikel tentang pembinaan olahraga di Indonesia. Mereka memanfaatkan informasi olahraga di media massa cetak untuk mendukung keberhasilan mereka dalam proses belajar mengajar, karena jenis cabang olahraga yang disajikan di media massa cetak sama dengan yang ada di kurikulum. Jenis informasi olahraga yang mereka manfaatkan untuk mendukung keberhasilan proses belajar mengajar adalah berupa berita dan artikel tentang kesehatan. Menurut mereka, tugas itu untuk merangsang minat para siswa untuk menyukai salah satu cabang olahraga. Hal itu dimaksudkan, untuk memasyarakatkan olahraga di kalangan para siswa dan diharapkan muncul bibit-bibit atlet potensial. Sedangkan, bentuk pemanfaatannya adalah dengan memberikan tugas kepada siswa untuk membuat kliping, dan melalui penyampaian langsung pada saat memberika materi praktek di lapangan. Cara ini dipandang efektif, karena semua siswa bisa langsung mempraktekkan.

Untuk tugas kliping, jenis informasi yang dimanfaatkan adalah artikel tentang pembinaan olahraga dan kesehatan. Ketiga guru pendidikan olahraga dan kesehatan di sekolah yang menjadi obyek penelitian juga pernah membuat beberapa soal ijuan tertulis (ketika masih ada ujian tertulis) yang materinya diambil dari informasi olahraga di media massa cetak. Dari segi penyajiannya, informasi olahraga di media massa cetak dinilai telah memenuhi kebutuhan guru pendidikan jasmani dan kesehatan dalam mendukung proses belajar mengajar. Menurut mereka, dari segi materi, informasi olahraga yang disajikan di media massa cetak sama dengan materi yang ada di dalam kurikulum yaitu antara lain: bola voli, sepakbola, atletik, bola basket, senam dan bulu tangkis. 


\section{Daftar Pustaka}

Donald P. Ely. 1994. Instructional Design and Development Participant's Note Book. Jakarta: TKPK Depdikbud, Jakarta.

Singgih D. Gunarsa. 1996. Psikologi Olahraga. Jakarta: PT BPK Gunung Mulia.

Lexy J. Moleong. 1998. Metodologi Penelitian Kualitatif. Bandung: Remaja Rosdakarya. 